\title{
Pearls \& Oy-sters: Angioplasty and Stenting as New Treatment Method for Cough Headache With Stenotic Internal Jugular Vein
}

\author{
Case Report With 12-Month Follow-up
}

Xiangyu Cao, MD,* Baomin Li, MD,* Hui Su, MD, Rongfei Wang, MD, Jun Wang, MD, Chenglin Tian, MD, Zhihua Du, MD, Xinfeng Liu, MD, Yunxia Zhang, MD, Xing Chen, PhD, Zhao Dong, MD, and Shengyuan Yu, MD Neurology ${ }^{\circledR}$ 2021;97:e964-e967. doi:10.1212/WNL.0000000000012152

\author{
Correspondence \\ Dr. Chen \\ xingc@buaa.edu.cn \\ or Dr. Dong \\ dong_zhaozhao@126.com
}

\section{Pearls}

- Drainage dysfunction of stenotic internal jugular veins (IJVs) is considered an etiology of cough headache as a result of fluctuation and imbalance of intracranial pressure.

- Angioplasty and stenting procedure has been shown to be a new effective method for treating cough headache caused by severe stenosis of IJVs.

\section{Oy-sters}

- It is inaccurate to determine the etiology of cough headache by a singular diagnostic imaging modality, emphasizing the need to use multimodal imaging modalities.

A 39-year-old man presented with symptoms including recurrent headaches lasting for several hours over the past 3 years, moderate to severe in intensity, localized on bilateral occipital and temporal areas, and sometimes accompanied by nausea, photophobia, and phonophobia, with no cranial autonomic symptoms. The headache was primarily provoked by sudden body postural changes and partially alleviated by resting, and gradually appeared during coughing, sneezing, and bending down, but was not triggered by sustained physical exercise. The neurologic examination was unremarkable and the lumbar opening pressure was $200 \mathrm{~mm} \mathrm{H}_{2} \mathrm{O}$ at rest but $>350 \mathrm{~mm} \mathrm{H}_{2} \mathrm{O}$ after Valsalva maneuver (VM). MRI showed Chiari malformation type I with cerebellar tonsil hernia, with normal enhancement imaging (figure). Magnetic resonance angiography and magnetic resonance venography (MRV) revealed no abnormalities. The patient was identified as having cough headache.

Color Doppler ultrasound showed normal bilateral IJVs at normal breathing, with bilateral retrograde venous flow at VM (768 ms on the right vs $312 \mathrm{~ms}$ on the left). Cerebral vascular angiography located stenoses of both IJVs. The patient was recommended indomethacin ( $75 \mathrm{mg}$ twice a day) to relieve pain and then dabigatran ( $150 \mathrm{mg}$ twice a day) to prevent thrombosis, but symptoms were not relieved during the 4-month follow-up. Following the third edition of the International Classification of Headache Disorders (ICHD-3), the patient was diagnosed with secondary cough headache rather than primary cough headache based on both his structural cranial abnormalities and clinical features, including age $<50$ years, primarily provoked by sudden body postural changes rather than coughing, lasting several hours, which is much longer than 1 minute, and no response to indomethacin. ${ }^{1}$

*These authors contributed equally to this work.

From the Department of Neurology (X. Cao, B.L., H.S., R.W., J.W., C.T., Z. Du, X.L., Y.Z., Z. Dong, S.Y.), Chinese PLA General Hospital; and Beijing Advanced Innovation Center for Biomedical Engineering (X. Chen), Beihang University, Beijing, China.

Go to Neurology.org/N for full disclosures. Funding information and disclosures deemed relevant by the authors, if any, are provided at the end of the article. 

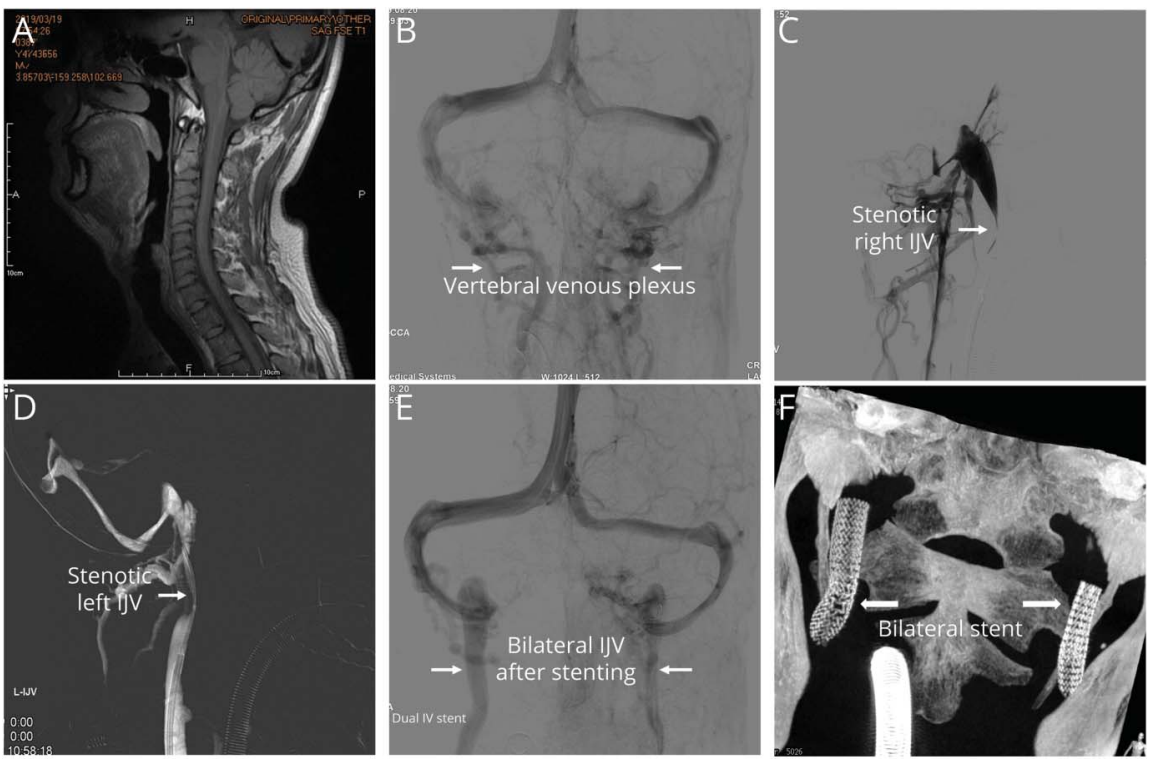

Images are from a 39-year-old man with bilateral IJV stenoses and Chiari malformation type I. (A) Sagittal T1-weighted MRI reveals cerebellar tonsillar herniation. (B) Angiography discloses severe stenoses in bilateral IJVs and enlarged vertebral venous plexus (arrows). (C) Venous angiography reveals severe stenosis at the right IJV (arrow). (D) The stenotic left IJV (arrow) and enlarged vertebral venous plexus. (E) Mild postprocedural residual stenosis and the vertebral vein plexus disappeared after stenting (arrows). (F) VasoCT scan shows the morphology of the stents after placement.

For this patient, surgical treatment of Chiari malformation type I was not suggested by neurosurgeons owing to the absence of indication. Therefore, we targeted IJV stenosesrelated cough headache by performing angioplasty and stenting as a new treatment approach.

The patient received dual antiplatelet therapy (aspirin $100 \mathrm{mg}$ daily and clopidogrel $75 \mathrm{mg}$ daily) for 4 days before the procedure. The thromboelastography mapping test for antiplatelet drugs was recommended, and the inhibition rates of arachidonic acid and adenosine diphosphate were higher than $50 \%$ and $40 \%$, respectively.

Angiogram revealed severe stenoses of the bilateral IJVs in the venous phase and slow outflow of the bilateral transverse sinus (figure, B-D). Following this, an $8 \mathrm{~F}$ guiding catheter was inserted into the IJV. A Renegade microcatheter was manually inserted across the stenotic segment. A pressure transducer connected with the Renegade microcatheter was used for functional assessment of IJV stenoses. The pressure gradient of bilateral IJVs was measured to be $9 \mathrm{~mm} \mathrm{Hg}$ (distal and proximal pressure of stenosis of the left and right IJVs were 14 and $5 \mathrm{~mm} \mathrm{Hg}, 13$ and $4 \mathrm{~mm} \mathrm{Hg}$, respectively).

A 0.014-inch $(300 \mathrm{~cm})$ Transend microwire was manipulated in the IJV. Following balloon inflation, 2 Precise stents were deployed in the bilateral stenotic IJVs. Angiography showed mild residual postprocedural stenoses of bilateral IJVs, and the VasoCT scan revealed full expansion of the stents (figure, E and F). Clopidogrel and aspirin were maintained for 6 months after the operation. During a 12-month follow-up, the headache was mostly relieved from coughing, sneezing, and bending down, but could appear when bowing the head.

\section{Discussion}

Chiari malformation type I is the most common cause of secondary cough headache, ${ }^{2}$ which manifests pressure difference between the ventricles and the lumbar subarachnoidal space after a VM. ${ }^{3}$ IJV stenosis is also a factor to alter intracranial pressure caused by drainage dysfunction, so it is speculated as another underlying etiology of cough headache. ${ }^{4,5}$ Our study reports a patient with cough headache diagnosed with pressure gradient across the IJV stenosis. This case led us to investigate the association between cough headache and IJV stenosis. We performed angioplasty and stenting as a new approach to treat IJVs stenosis-induced cough headache with satisfactory outcomes.

This study reveals the importance and necessity of multimodal imaging to diagnose cough headache, especially for those with additional headache triggers, higher pain intensities, and diverse headache duration (as observed in the present case). ${ }^{3}$ For this case, we observed normal MRV and right internal jugular reflux, with opposite results from angiography. Because the intracranial and extracranial venous system is complex with variability between individuals and is often asymmetric, Dolic et al. ${ }^{6}$ regarded it almost impossible to determine the relevance of a single structural or hemodynamic venous abnormality and emphasized the need to use multimodal imaging modalities.

The diagnostic reasoning of cough headache was based on ICHD-3. Although the patient had been diagnosed with secondary cough headache, other possible causes of headache were systematically assessed but were eventually precluded. ${ }^{7}$ ICHD-3 diagnosis 6.6, "Headache attributed to cranial venous disorder," could be ruled out because the patient did not 
present with cerebral venous thrombosis. Moreover, this patient did not fulfill the diagnostic criteria of ICHD-3 diagnosis 7.7, "Headache attributed to Chiari malformation type I," for several reasons. First, there is no evidence of a clear relation between headache development and Chiari malformation progression, or no surgical treatment for the diagnosis. Second, headache episodes are not associated with any symptoms or clinical signs of brainstem, cerebellar, lower cranial nerve, or cervical spinal cord dysfunction, which do not satisfy the criteria in the ICHD-3. ${ }^{7}$ However, we could not exclude this diagnosis because the headache did not disappear after treating the stenotic IJV.

Angioplasty and stenting have been used to treat stenotic IJV since Ryu et al. ${ }^{8}$ used IJV stent for treating traumatic occlusion in 1997. Afterwards, several IJV stents were used to treat chronic cerebrospinal venous insufficiency that might induce multiple sclerosis, tinnitus, visual impairment, dizziness, sleep disturbance, and neck discomfort or pain. ${ }^{9}$ In recent years, angioplasty and stenting for IJV have been rarely used because of the complex IJV variability among different individuals. However, a relatively low rate of restenosis and complications have proved stenting a safe operation. ${ }^{10}$ Donnet et al. ${ }^{11}$ performed craniocervical MRV and found stenosis of venous sinus or IJV in 5/7 patients in the cough headache group; they did not perform any surgical intervention for the stenosis. Our previous study has confirmed that stent implantation or balloon dilation of cerebral venous sinus can decrease intracranial pressure and improve symptoms immediately. ${ }^{10}$ We further extended the treatment to IJVs and investigated the efficacy of using angioplasty and stenting to treat cough headache with severe stenotic IJVs.

In this study, we performed stenting to treat cough headache for the first time given the following conditions. First, the symptoms of cough headache did not improve from the conservative treatment by indomethacin and dabigatran for consecutive 4 months. Second, the pressure difference between the proximal and distal narrow regions of the bilateral IJVs were both $>8 \mathrm{~mm} \mathrm{Hg}$, falling into the range at which we usually chose stenting treatment for intracranial venous sinus. ${ }^{10}$ Third, the enlarged vertebral venous plexus was present (disappeared after the IJV stent implantation). The rationale to treat this patient with cough headache by IJV stenting was supported by the final clinical outcome. Despite the in-depth investigation of stenosis-induced cough headache and the new effective treatment reported in this study, the study has some limitations. This is a single case association between cough headache and IJVs stenting, which needs to be confirmed in future studies. Moreover, Chiari malformation type I was not treated, so its possibility as a symptomatic cause of cough headache could not be precluded.

\section{Acknowledgment}

The authors thank the patient, the patient's family, and the physicians and nurses involved in the care of this patient. This study was performed with approval from the institutional ethics committee of the Chinese PLA General Hospital
(S2019-359-02). The patient and the authorized representative were explicitly informed and signed written informed consent for the angioplasty and stenting.

\section{Study Funding}

This study was supported by the National Natural Science Foundation of China (62074013 and 81771200).

\section{Disclosure}

The authors report no disclosures relevant to the manuscript. Go to Neurology.org/ $\mathrm{N}$ for full disclosures.

\begin{tabular}{|c|c|c|}
\hline Name & Location & Contribution \\
\hline $\begin{array}{l}\text { Xiangyu } \\
\text { Cao, MD }\end{array}$ & $\begin{array}{l}\text { Department of Neurology, } \\
\text { Chinese PLA General } \\
\text { Hospital, Beijing, China }\end{array}$ & $\begin{array}{l}\text { Designed and conceptualized } \\
\text { study, drafted the manuscript } \\
\text { for intellectual content }\end{array}$ \\
\hline $\begin{array}{l}\text { Baomin Li, } \\
\text { MD }\end{array}$ & $\begin{array}{l}\text { Department of Neurology, } \\
\text { Chinese PLA General } \\
\text { Hospital, Beijing, China }\end{array}$ & $\begin{array}{l}\text { Designed and conceptualized } \\
\text { study, angiography and } \\
\text { operation }\end{array}$ \\
\hline Hui Su, MD & $\begin{array}{l}\text { Department of Neurology, } \\
\text { Chinese PLA General } \\
\text { Hospital, Beijing, China }\end{array}$ & $\begin{array}{l}\text { Patient management and } \\
\text { follow-up }\end{array}$ \\
\hline $\begin{array}{l}\text { Rongfei } \\
\text { Wang, MD }\end{array}$ & $\begin{array}{l}\text { Department of Neurology, } \\
\text { Chinese PLA General } \\
\text { Hospital, Beijing, China }\end{array}$ & $\begin{array}{l}\text { Patient management and } \\
\text { follow-up }\end{array}$ \\
\hline $\begin{array}{l}\text { Jun Wang, } \\
\text { MD }\end{array}$ & $\begin{array}{l}\text { Department of Neurology, } \\
\text { Chinese PLA General } \\
\text { Hospital, Beijing, China }\end{array}$ & $\begin{array}{l}\text { Major role in angiography and } \\
\text { operation }\end{array}$ \\
\hline $\begin{array}{l}\text { Chenglin } \\
\text { Tian, MD }\end{array}$ & $\begin{array}{l}\text { Department of Neurology, } \\
\text { Chinese PLA General } \\
\text { Hospital, Beijing, China }\end{array}$ & $\begin{array}{l}\text { Major role in angiography and } \\
\text { operation }\end{array}$ \\
\hline $\begin{array}{l}\text { Zhihua Du, } \\
\text { MD }\end{array}$ & $\begin{array}{l}\text { Department of Neurology, } \\
\text { Chinese PLA General } \\
\text { Hospital, Beijing, China }\end{array}$ & $\begin{array}{l}\text { Major role in angiography and } \\
\text { operation }\end{array}$ \\
\hline $\begin{array}{l}\text { Xinfeng } \\
\text { Liu, MD }\end{array}$ & $\begin{array}{l}\text { Department of Neurology, } \\
\text { Chinese PLA General } \\
\text { Hospital, Beijing, China }\end{array}$ & $\begin{array}{l}\text { Major role in angiography and } \\
\text { operation }\end{array}$ \\
\hline $\begin{array}{l}\text { Yunxia } \\
\text { Zhang, MD }\end{array}$ & $\begin{array}{l}\text { Department of Neurology, } \\
\text { Chinese PLA General } \\
\text { Hospital, Beijing, China }\end{array}$ & $\begin{array}{l}\text { Patient management and } \\
\text { follow-up }\end{array}$ \\
\hline $\begin{array}{l}\text { Xing Chen, } \\
\text { PhD }\end{array}$ & $\begin{array}{l}\text { Beijing Advanced Innovation } \\
\text { Center for Biomedical } \\
\text { Engineering, Beihang } \\
\text { University, Beijing, China }\end{array}$ & $\begin{array}{l}\text { Interpreted the data, revised } \\
\text { the manuscript for } \\
\text { intellectual content }\end{array}$ \\
\hline $\begin{array}{l}\text { Zhao Dong, } \\
\text { MD }\end{array}$ & $\begin{array}{l}\text { Department of Neurology, } \\
\text { Chinese PLA General } \\
\text { Hospital, Beijing, China }\end{array}$ & $\begin{array}{l}\text { Interpreted the data, revised } \\
\text { the manuscript for } \\
\text { intellectual content }\end{array}$ \\
\hline $\begin{array}{l}\text { Shengyuan } \\
\text { Yu, MD }\end{array}$ & $\begin{array}{l}\text { Department of Neurology, } \\
\text { Chinese PLA General } \\
\text { Hospital, Beijing, China }\end{array}$ & $\begin{array}{l}\text { Interpreted the data, revised } \\
\text { the manuscript for } \\
\text { intellectual content }\end{array}$ \\
\hline
\end{tabular}

\section{References}

1. Alvarez R, Ramón C, Pascual J. Clues in the differential diagnosis of primary vs secondary cough, exercise, and sexual headaches. Headache. 2014;54(9):1560-1562.

2. Cordenier A, De Hertogh W, De Keyser J, et al. Headache associated with cough: a review. J Headache Pain. 2013;14:42.

3. Chen PK, Fuh JL, Wang SJ. Cough headache: a study of 83 consecutive patients. Cephalalgia. 2009;29:1079-1085. 
4. Williams B. Cough headache due to craniospinal pressure dissociation. Arch Neurol. 1980;37:226-230.

5. Liu H, Cao X, Zhang M, et al. A case report of cough headache with transient elevation of intracranial pressure and bilateral internal jugular vein valve incompetence: a primary or secondary headache? Cephalalgia. 2018;38(3):600-603.

6. Dolic K, Siddiqui A, Karmon $\mathrm{Y}$, et al. The role of noninvasive and invasive diagnostic imaging techniques for detection of extra-cranial venous system anomalies and their development variants. BMC Med. 2013;11:155.

7. Headache Classification Committee of the International Headache Society. The International Classification of Headache Disorders, 3rd edition. Cephalalgia. 2018;38(1):1-211.
8. Ryu RK, Duke BJ, Brega KE, Coldwell DM. Percutaneous endoluminal stent placement for traumatic occlusion of the internal jugular vein. J Vasc Interv Radiol. 1997; 8(3):359-362.

9. Zhou D, Ding JY, Ya JY, et al. Understanding jugular venous outflow disturbance. CNS Neurosci Ther. 2018;24(6):473-482.

10. Liu X, Di H, Wang J, et al. Endovascular stenting for idiopathic intracranial hypertension with venous sinus stenosis. Brain Behav. 2019;9(5):e01279.

11. Donnet A, Valade D, Houdart E, et al. Primary cough headache, primary exertional headache, and primary headache associated with sexual activity: a clinical and radiological study. Neuroradiology. 2013;55:297-305. 


\section{Neurology}

\section{Pearls \& Oy-sters: Angioplasty and Stenting as New Treatment Method for Cough Headache With Stenotic Internal Jugular Vein: Case Report With 12-Month Follow-up Xiangyu Cao, Baomin Li, Hui Su, et al.}

Neurology 2021;97;e964-e967 Published Online before print May 4, 2021

DOI 10.1212/WNL.0000000000012152

This information is current as of May 4, 2021

\section{Updated Information \& Services}

References

Subspecialty Collections

Permissions \& Licensing

Reprints including high resolution figures, can be found at: http://n.neurology.org/content/97/9/e964.full

This article cites 11 articles, 0 of which you can access for free at: http://n.neurology.org/content/97/9/e964.full\#ref-list-1

This article, along with others on similar topics, appears in the following collection(s):

\section{All Cerebrovascular disease/Stroke}

http://n.neurology.org/cgi/collection/all_cerebrovascular_disease_strok e

All Clinical Neurology

http://n.neurology.org/cgi/collection/all_clinical_neurology

All Headache

http://n.neurology.org/cgi/collection/all_headache

Palliation pain

http://n.neurology.org/cgi/collection/palliation_pain

Secondary headache disorders

http://n.neurology.org/cgi/collection/secondary_headache_disorders

Information about reproducing this article in parts (figures,tables) or in its entirety can be found online at:

http://www.neurology.org/about/about_the_journal\#permissions

Information about ordering reprints can be found online:

http://n.neurology.org/subscribers/advertise

Neurology ${ }^{\circledR}$ is the official journal of the American Academy of Neurology. Published continuously since 1951, it is now a weekly with 48 issues per year. Copyright (C 2021 American Academy of Neurology. All rights reserved. Print ISSN: 0028-3878. Online ISSN: 1526-632X.

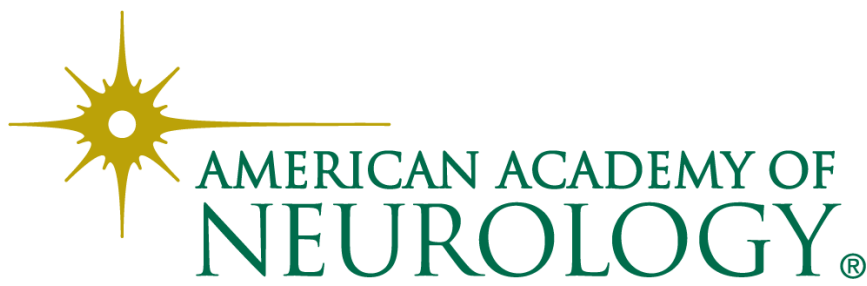

